\title{
アクティブ振動制御系内のパワー流れの測定
}

\section{Measurement of power flow in active vibration control system}

\author{
○正 中原 健志 (九産大), 正 藤本 孝 (九産大)
}

Takeshi NAKAHARA, Kyushu Sangyo University, 2-3-1, Matsukadai, Higashi-ku, Fukuoka, 813-8503

Takashi FUJIMOTO, Kyushu Sangyo University, 2-3-1, Matsukadai, Higashi-ku, Fukuoka, 813-8503

Key Words: Power Flow, Vibration Control, Piezo-Element, Energy Regeneration, Class D Amplifier

\section{1. 緒論}

アクティブ振動制御はセミアクティブやパッシブ振動制御と 比較して一般に高い制振性能を得られることが知られているが, アクチュエータ駆動用のエネルギー消琒が關題と考えられてい る.しかし，振動系のエネルギーに着目して考えるとアクティ ブ振動制御により振動系の振幅を抑えるということは, 振動系 に外部からエネルギーを供給するのではなく, アクチュエータ を介して振動系のエネルギーを外部に放出することであると考 えられる。これをアクチュエータ側からみると平均的には振動 系に対して負の仕事をしていることになるので, アクチュエー 夕は外部から供給される駆動用エネルギーを消费するのではな く，振動系からのエネルギーを回生していると考えられる。

特にスマート構造でよく用いられる圧電アクチュエータでは, 電磁アクチュエータの巻線抵抗による損失のようなアクチュ エータ内での損失が無いため, 振動系からのエネルギーを効率 よく霞気エネルギーに回生できると考えられる.この考えに基 ついて著者らは, 従来のアクティブ振動制御系において外部か らのエネルギー供給が必要となる原因がアクチュエータ歌動用 増幅器の損失であることを示し, スイッチング動作を基本とし て損失が極めて小さい D 級増幅器 (1) を圧電アクチュエータの 駆動に用いることにより,アクティブ振動制御時に振動系の持 つエネルギーを電気エネルギーに回生できることをシミュレー ションにより示している(2)(3).

本論文では，圧電アクチュエータを用いた片持ち梁の振動制 御実験装置を製作し, 電力計を用いて系内のパワー（電力）の流 れを測定することにより，

・振動制御時の圧電アクチュエータは電力を消費するのでは なく, 振動系のエネルギーを電力として回生していること

・振動制御時のエネルギー消費の原因が従来型のアクチュ エータ駆動用増幅器（リニア増幅器）の損失であること

-アクチュエータ駆動用増幅器として高効率な D 級増幅器を 用いれば,アクチュエータが回生した電力を電源まで回生 できること

の 3 点を確認する.

\section{2. 実験装置}

2-1. 圧電素子と片持ち梁 本論文で対象とする片持ち梁を 図 1 に示す。この片持ち梁の両面には圧電素子 (MIDE 社製 QP20n) が貼り付けられており, 振動制御用のセンサ, アクチュ エータおよび外乱発生用のアクチュエータとして用いる. MIDE 社製 QP-20n は図 2 に示すように 2 枚の圧電素子を重ね合わせ てラミネートした構造になっており，梁の両面に貼り付けられ たそれぞれの素子の役割は図 3 に示すとおりである. 合計 4 枚 の圧電素子のうち 2 枚を制御用アクチュエータとして使用し, 残りを 1 枚ずつ外乱発生用アクチュエータおよびセンサとして 使用している：また，図中の記号 $V_{a}, V_{d}, V_{s}$ および $I_{a}, I_{d}, I_{s}$
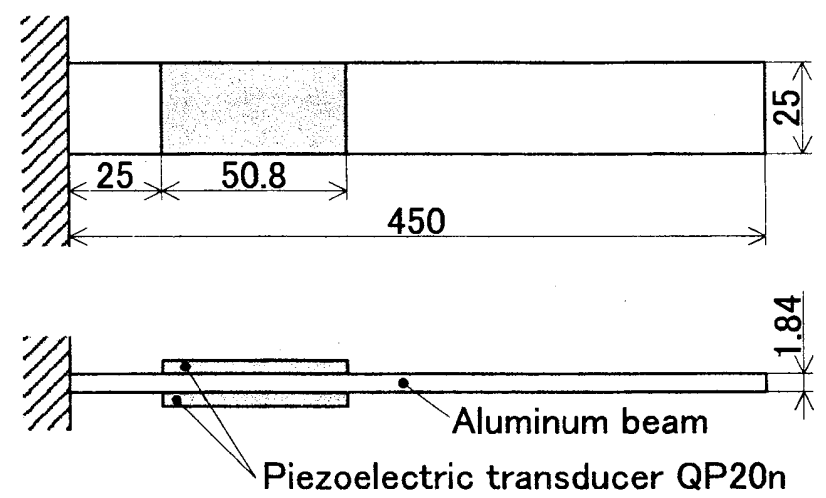

Fig. 1. Cantilever beam with piezoelectric elements

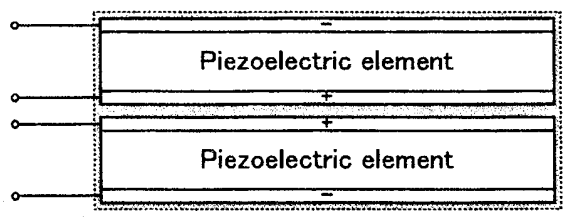

Fig. 2 QP20n piezoelectric transducer

Quick Pack QP2On Piezoelectric Transducer

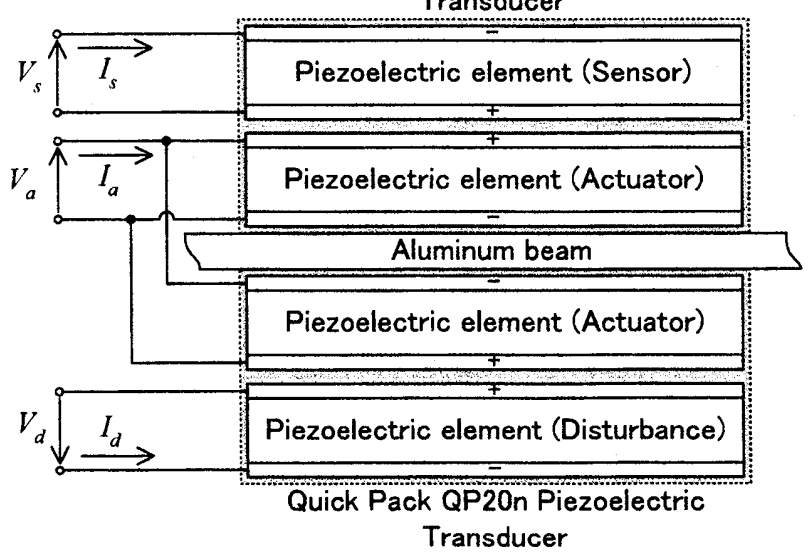

Fig. 3 Connection of piezoelectric elements

は，それぞれの素子の電圧および電流を表している.

2-2. 制御系の構成図 4 と図 5 は, それぞれ従来型のリニア 增幅器と高効率な D 級増幅器を用いる場合のアクティブ振動制 御系の構成を示す．どちらの場合も，梁が振動するとセンサ用圧 電素子には速度に比例する電流 $I_{s}$ が流れ，この電流が電流一電 圧変換回路により電圧信号に変換される.この速度に比例する 


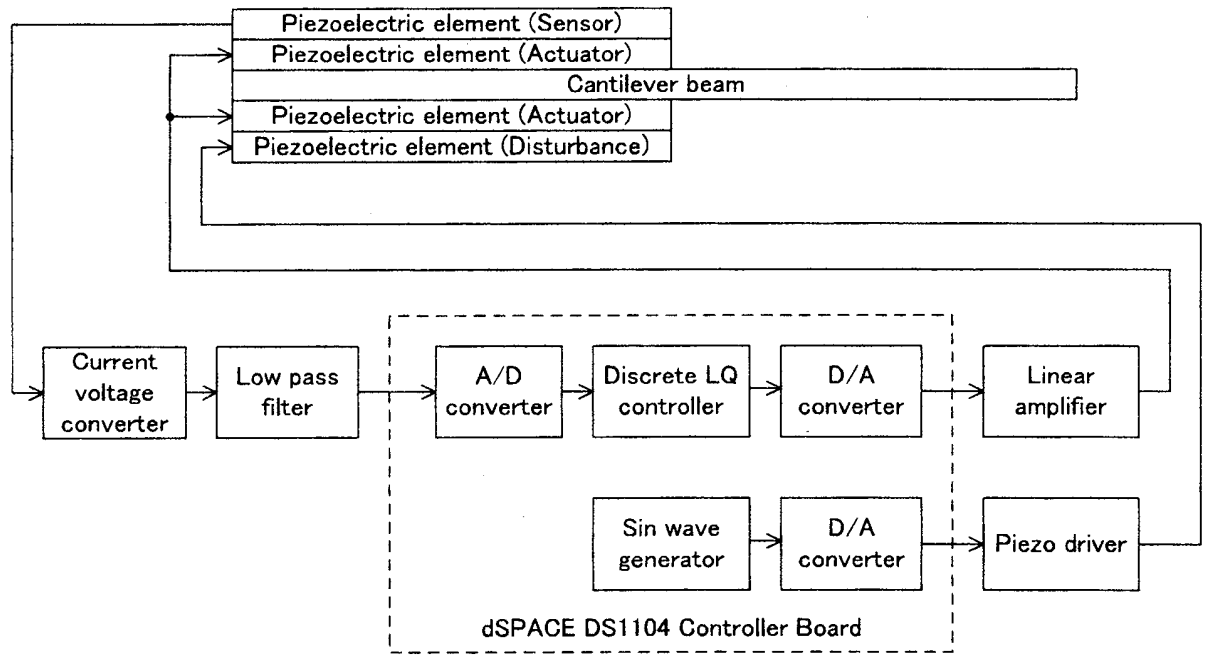

Fig. 4 Control system using linear amplifier

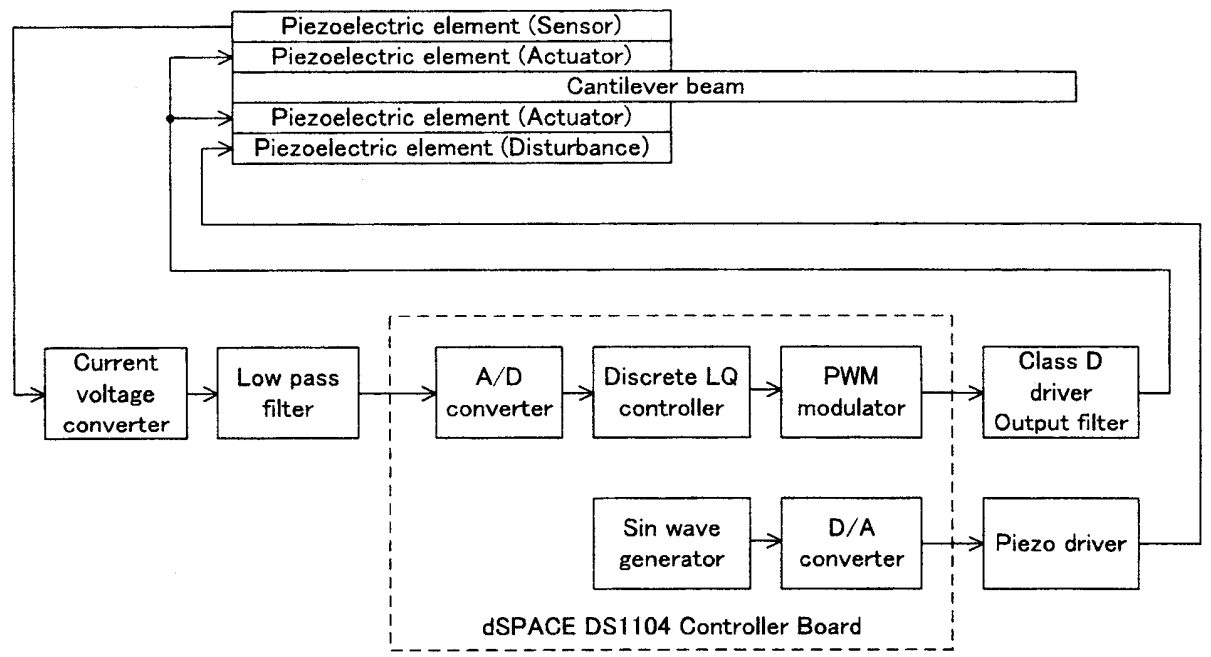

Fig. 5 Control system using class D amplifier

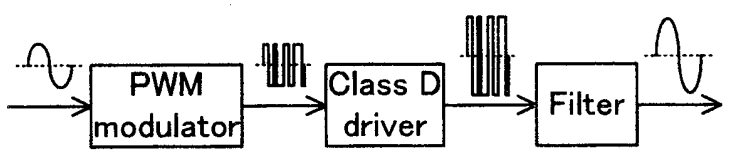

Fig. 6 Wave forms in class $\mathrm{D}$ amplifier

電圧信号は, 高次モードとノイズの影響を抑制するためのロー パスフィルタを通って, dSPACE 社製 DS1104 制御ボードに実 装されたデジタル制御器に入力される. デジタル制御器からは 振動を抑制するためのアクチュエータへの制御入力の信号が出 力され，この信号がそれぞれの増幅器で増幅されて制御用アク チュエータにフィードバックされる構造になっている. 制御器 は最適レギュレータと同一次元オブザーバの組み合わせとして 設計されており, 増幅器の種類によらず同じ制御器を用いるこ とで, 増幅器の違いによるパワーの流れの違いを比較できるよ うにする.

2-3. D 級増幅器一般的な D 級増幅器は, PWM 変調器, D 級出力段, 出力フィルタから構成されており, 図 6 に示すよう に增幅したい信号は PWM 変調器で PWM 信号に変調されてか
ら D 級出力段で増幅される。この増幅された PWM 信号から PWM 変調で付加された高周波成分を出力フィルタにより取り 除くことで, 元の信号を增幅した信号を得ることができる.こ のように D 級増幅器では元の信号そのものではなく PWM 信号 を堌幅しているため，原理的に損失のない D 級出力段のスイッ チの ON-OFF のみで増幅が可能であり, 効率が極めて高いとい う特徵を持っている. 本論文の実験装置では, DS1104制御ボー ド内蔵の PWM 変調器を使用し，ここから出力される PWM 信 号を図 7 に示す D 級出力段と出力フィルタを介して制御用アク チュエータに出力している. 図7 の回路の入力である $V_{\mathrm{PWM}}$ は DS1104 制御ボードから出力される TTL レベルの PWM 信号で あり， $\bar{V}_{\mathrm{PWM}}$ は図 8 に示すように $\mathrm{PWM}$ 信号 $V_{\mathrm{PWM}}$ を反転した 信号である. 図 8 では, $V_{\mathrm{PWM}}$ と $\bar{V}_{\mathrm{PWM}}$ の双方が $0 \mathrm{~V}$ となる期 間が存在するが, これはデッドタイムと呼ばれるものであり，ト ランジスタのスイッチング遅れのために上下のトランジスタが 同時に ON 状態となり短絡することを防止している，図 9 は図 7 の回路を説明のため簡略化したものであり, TR1 から TR4 は $V_{\text {PWM }}$ と $\bar{V}_{\text {PWM }}$ により表 1 のようにスイッチとして動作するこ とで PWM 信号を増幅している. 


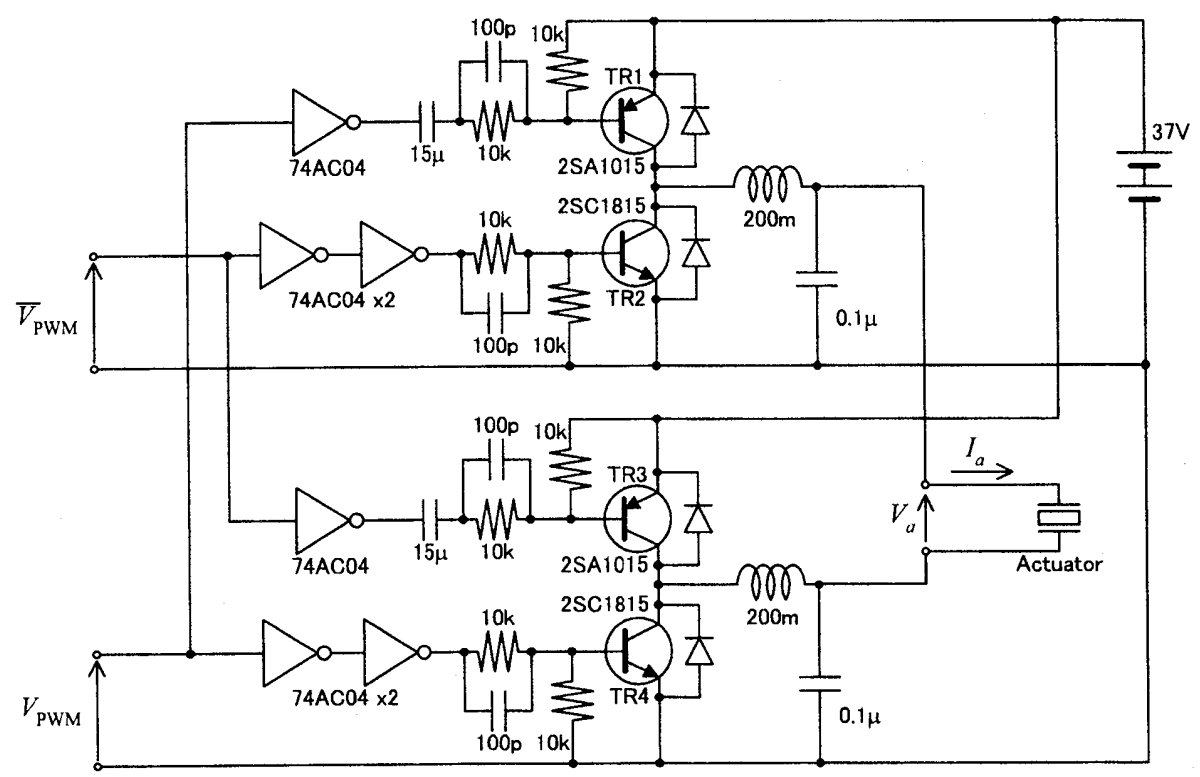

Fig. 7 Class D driver and output filter

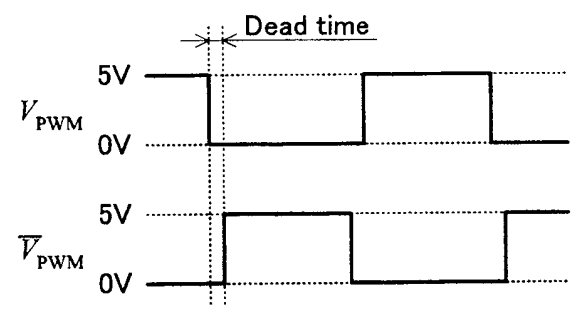

Fig. 8 Wave forms of $V_{\mathrm{PWM}}$ and $\bar{V}_{\mathrm{PWM}}$

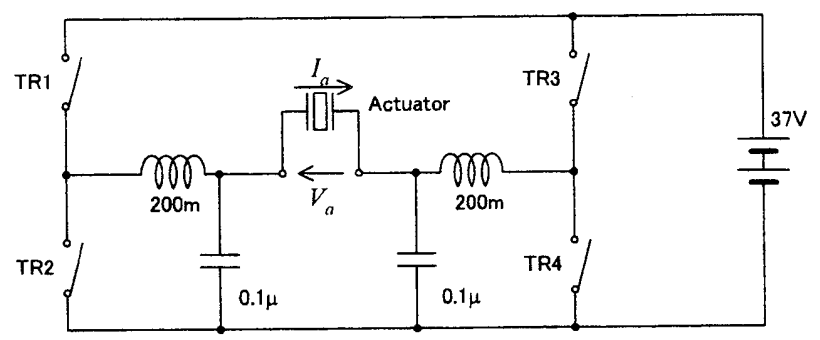

Fig. 9 Simplified circuit of class D driver and output filter

Table 1 Switching logic

\begin{tabular}{|c|c|c|c|}
\hline$V_{\mathrm{PWM}}$ & $\vec{V}_{\mathrm{PWM}}$ & TR1 and TR4 & TR2 and TR3 \\
\hline $5 \mathrm{~V}$ & $0 \mathrm{~V}$ & ON & OFF \\
\hline $0 \mathrm{~V}$ & $5 \mathrm{~V}$ & OFF & ON \\
\hline $0 \mathrm{~V}$ & $0 \mathrm{~V}$ & OFF & OFF \\
\hline
\end{tabular}

\section{3. 制御実験とパワーの流れの測定}

3-1. 制御効果の確認呵，製作した装置のアクティブ振動 制御系が機能することを確認するため, 固定端から $200 \mathrm{~mm}$ の位 置での梁の変位をレーザ変位計で測定し, 制御の有無による違い を比較する. 外乱としては, 梁の 1 次固有振動数に近い $8.12 \mathrm{~Hz}$ で振幅 $120 \mathrm{~V}$ の正弦波電圧 $V_{d}$ を外乱用アクチュエータに加え る. 図 10 と図 11 は，それぞれリニア増幅器を用いた場合と D
級増幅器を用いた場合の結果を示したものである．どちらの場 合も制御により振幅が低減されており，同一の制御器を用いて いるのでほぼ同等の効果が得られていることが分かる.

3-2. パワーの流れの測定図 12 は, アクティブ振動制御系内 のパワーの流れを簡潔に示したものであり, 増幅器には直流電 源から電力が供給され, 制御用アクチュエータには增幅器から 電力が供給されている. また, 外乱発生用アクチュエータには圧 電素子駆動用増幅器から外乱のパワーとして電力が供給されて いる. 実験では, この3つの電力を電力計 (横河電機製 WT210) により測定することで系内のパワーの流れを明らかにする. な お, 図 12 の矢印の向きに流れるパワーを正の電力と定義し, 電 力が負の值を取るときは矢印と反対向きのパワーの流れを示す ものとする. 図 13 と図 14 は, それぞれリニア増幅器を用いた 場合と D 級増幅器を用いた場合の測定結果であり, 外乱として 梁の 1 次固有振動数に近い $8.12 \mathrm{~Hz}$ の正弦波電圧 $V_{d}$ を外乱用ア クチュエータに加え, その振幅を変化させながら電力の変化を 測定した．まず，外乱用アクチュエータに入力される電力を見 ると, どちらの増幅器を用いた場合も常に正であり外乱振幅の 増大とともに增大している. 次に制御用アクチュエータに入力 される電力を見ると, どちらの増幅器を用いた場合も常に負で あり図 12 の矢印とは反対向きにパワーが流れていることが分か る.これは，振動制御時のアクチュエータが振動系からエネル ギーを取り除くことで振動を抑制しており, 取り除いたエネル ギーが電力として回生されアクチュエータから增幅器に流れて いることを示している. 最後に, 増幅器に入力される電力を見 ると, 増幅器の種類により大きく異なっている. リニア増幅器 を用いた場合には常に正であり, 外乱振幅の増大にともない增 大する傾向を示している. これは, 常に図 12 の矢印の向きのよ うに電源からリニア增幅器にパワーが流れていることを示して いる. リニア増幅器を用いた場合のパワーの流れの向きをまと めると図 15 に示すようになる。つまり,リニア増幅器には電源 とアクチュエータの双方からパワーが流れ込み、リニア増幅器 内の損失として熱に変換されていることを示している．このよ うにアクチュエータから増幅器にパワーが流れている状況でも リニア増幅器が電源からの電力を消費してしまい, 外乱の増大 とともに消費電力も増大する原因は, リニア増偪器の必要とす 


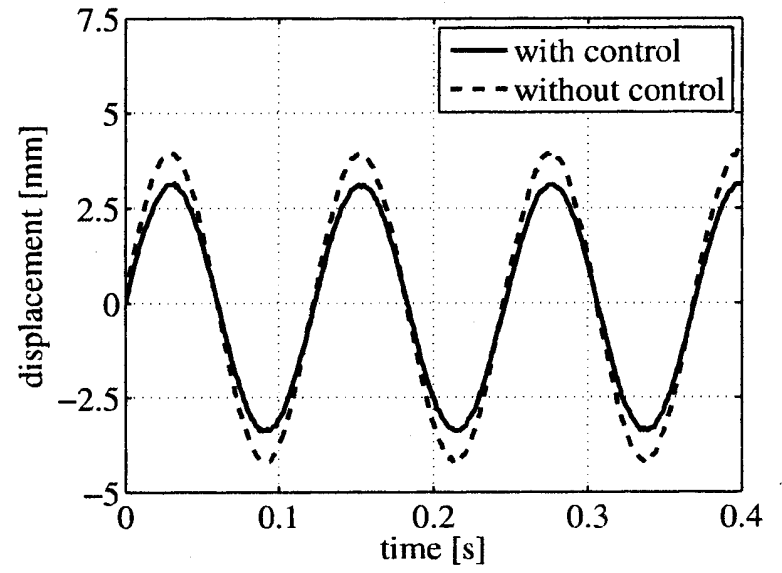

Fig. 10 Displacement of cantilever beam driven by linear amplifier

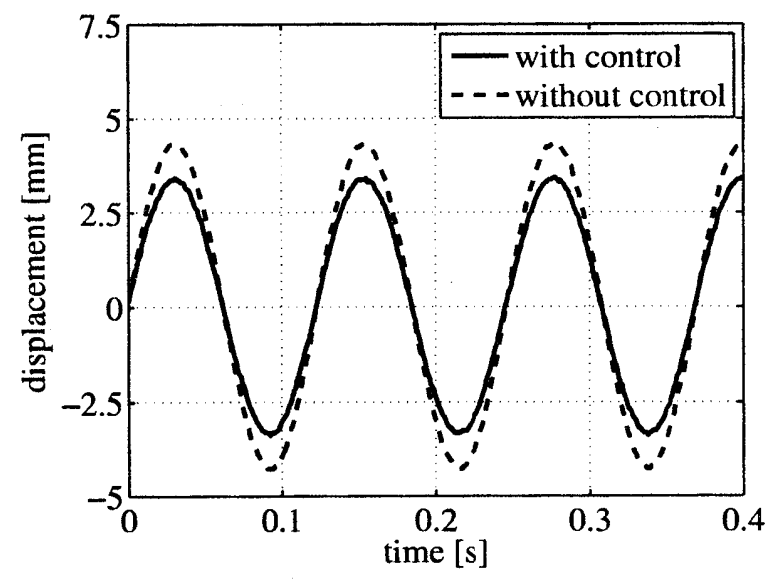

Fig. 11 Displacement of cantilever beam driven by class $D$ amplifier

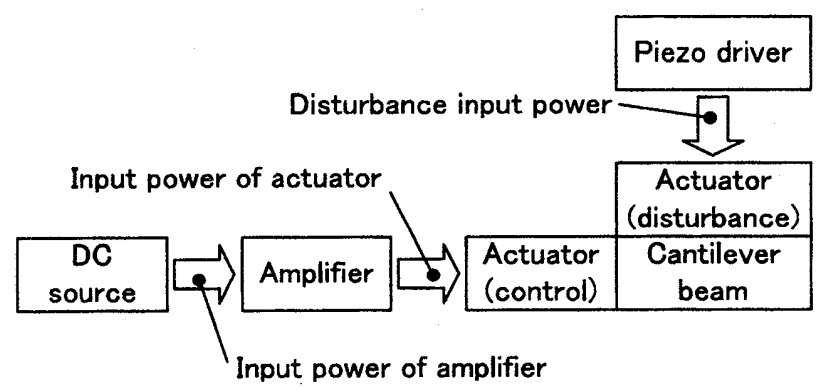

Fig. 12 Power flow in the system

る電力が理論的にアクチュエータを流れる電流の絶対值に比例 して常に正となるため ${ }^{(2)}$ と考えられる.

一方，D級増幅器を用いた場合には，外乱振幅が小さい領域で は增幅器に入力される電力は正であるが, 外乱振幅の增大ととも に減少し, 外乱振幅が大きい領域では增幅器に入力される電力 が負になっている. また， $\mathrm{D}$ 級増幅器に入力される電力とアク チュエータに入力される電力の差である増幅器の損失は, ほぼ 一定であり外乱振幅が增大するとやや減少する傾向を示してい る. これらの傾向は, D 級増幅器の内部損失は外乱振幅により 大きく変化することが無く, 外乱振幅が增大してアクチュエー タが回生する電力が大きくなると D 級増幅器の内部損失を上回

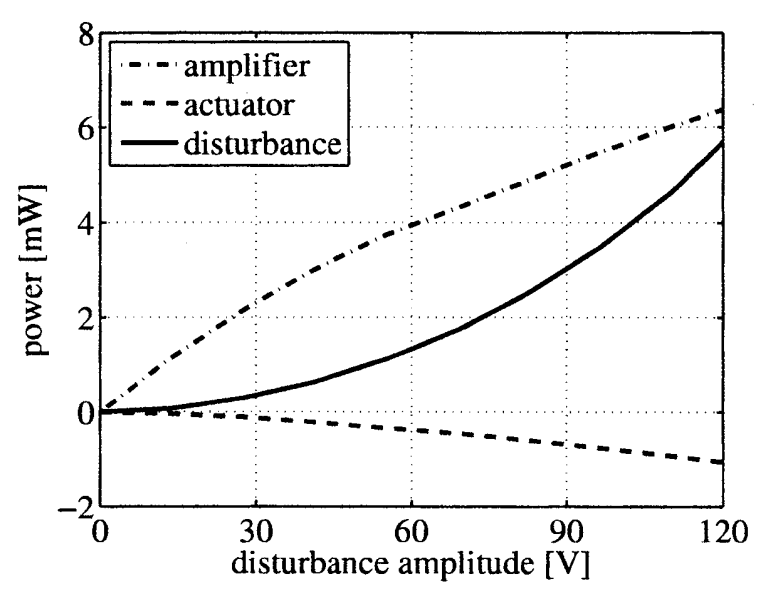

Fig. 13 Power in the system using linear amplifier(with control)

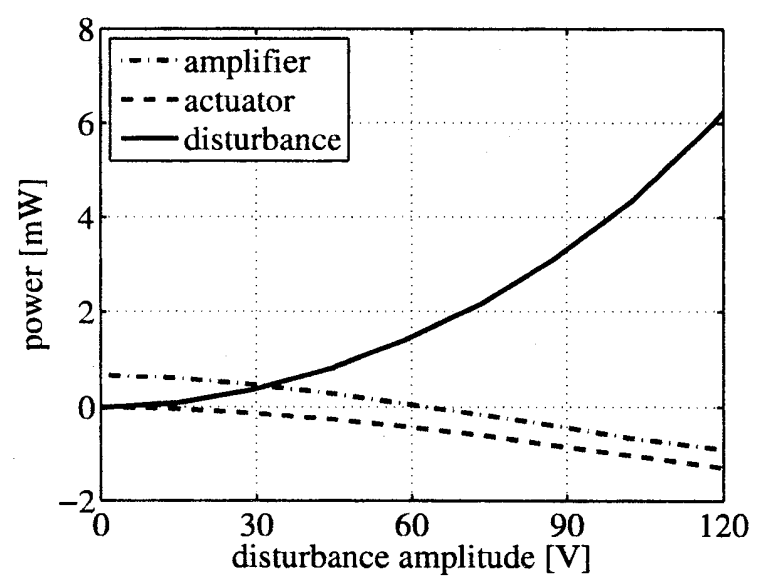

Fig. 14 Power in the system using class D amplifier(with control)

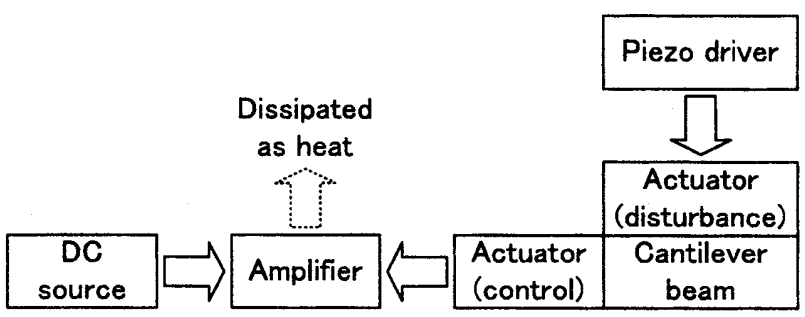

Fig. 15 Power flow in the system using linear amplifier

り，電源側へとパワーが流れることを意味している．このとき のパワーの流れの向きをまとめると図 16 に示すようになる.

\section{4. 結論}

本論文の結論を以下にまとめる.

・片持ち梁を対象として圧電アクチュエータを用いたアク ティブ振動制御系の実験装置を製作し, 系内のパワーの流 れを電力計により測定した.

・振動制御時の圧電アクチュエータに入力される電力は負と なり,アクチュエータが振動系から取り除いたエネルギー が電力として回生され, アクチュエータから增幅器に流れ ることを示した. 


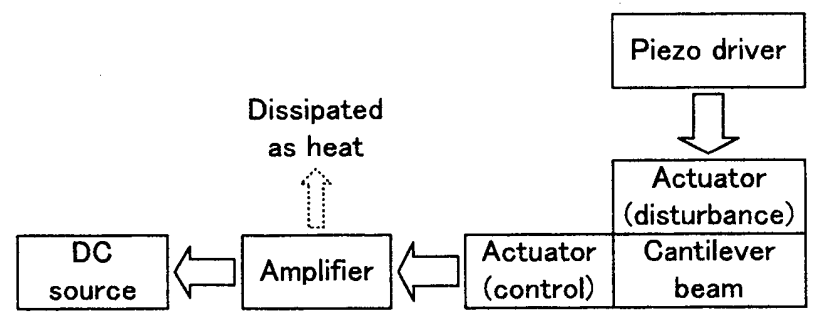

Fig. 16 Power flow in the system using class D amplifier

- 压電アクチュエータの駆動にリニア増幅器を用いた場合に は, 雷源から増幅器に電力が流れ, アクチュエータが回生 した電力と合わせて增幅器の損失として散逸することを示 した.

・ リニア増幅器の代わりに高効率な $\mathrm{D}$ 級増幅器を用いること で, アクチュエータが回生した電力の一部を電源に回生で きることを示した.

・アクティブ振動制御ではアクチュエータ駆動用のエネル ギーが必要であるという従来の認識は, 少なくとも圧電乃 クチュエータを用いる場合には正しくなく，正しくは増幅 器の損失がエネルギー消費の原因と考えられる.

\section{参考文献}

(1) 本田潤，D級/ディジタルアンプの設計と製作， C Q出版 社, 2004

（2）中原健志, D級增幅器によるスマート構造のエネルギー回 生振動制御（第 1 報, 等価回路モデルと回路シミュレータ を用いた数值解析による検討), 日本機械学会論文集 (C 編), Vol.74, No.738, 2008, pp.259-268

(3) 中原健志, 藤本孝, 機能モデルによるスマート構造のエネ ルギー回生振動制御のシミュレーション, D\&D2008 CDROM 論文集, 講演番号 217,2008 